\title{
The Reinvention of Brazil and Other Metamorphoses in the World of Chicago Samba'
}

\author{
Bernadete Beserra - Universidade Federal do Ceará
}

\section{Introduction}

Unlike Carmen Miranda and Antonio Carlos Jobim who came to the United States under the auspices of entrepreneurs strategically placed to integrate them into the cultural market, the immigrants in this article followed another trajectory. Many of them scarcely believed that they had the talents that immigrant life awoke in them. ${ }^{2}$ The discovery of Brazil as a narrative and a market for samba drove many to occupations they never dreamed of. Despite the problems this narrative would bring them, these immigrants benefited from its existence and used it strategically to escape the destiny the market imposes on most immigrants, transforming them, as Sayad (1998) observed, into cheap labor rather than treating them as émigrés with different histories and dispositions.

One can argue that, in the case of the Brazilian immigrants who exploit samba in Chicago, their integration, and that of those who negotiate their own culture, constantly emphasizes that they are above all émigrés. But more than this: their immigration seems to have more to do with the values and richness of their culture (in this case, nation) than with what is commonly

\footnotetext{
1 I thank Rémi Lavergne for the insights, suggestions and for wanting to see this article written. I also thank Rosemary Galli who kindly accepted to revise the English version and two anonymous Vibrant reviewers for their valuable comments made in an earlier version.

2 The research in which this article is based, entitled "By way of Samba and Capoeira: Brazilian Cultural and Political Coalitions in Chicago", was undertaken between August 2006 and August 2007. It was part of a post-doctoral fellowship program coordinated by Frances Aparicio and sponsored by the Latin and Latin American Studies Program, University of Illinois, at Chicago in collaboration with the Rockefeller Foundation. The aim of the program Latino Chicago: A Model for Emerging Latinidades? was to facilitate more systematic research on historical and contemporary cultural transformations among the diverse Latino communities in Chicago and their implications for understanding identity, migration, resistance, racism, cultural conflict and survival.
} 
supposed to be their problem. In principle, this inverts the most common notion of immigration: that of searching in another place for what is lacking in your own. The problem, however, is that the country or culture that is represented by the immigrant who works with cultural goods is not in fact his country or his culture but the country or culture that is presented in the narratives that circulate about them in the country of destination.

Like other narratives and discourses forged in the space of colonial domination, the narrative about Brazil is fed by stereotypes, which according to Bhabha (2007: 95), "must always be in excess of what can be empirically proved or logically construed". In this way, immigrants who work with Brazilian culture face the challenge of realizing the representations of Brazil created from this narrative and constructing their integration within these limits. Hence, they must dialog with these stereotypes and often reinforce them through their social practices. Their subjection to a narrative that precedes them and that tends to replace their own personal experiences makes these immigrants, like others, creatures rather than creators. In spite of this, the opportunity they have to manipulate their own culture, even if by displaying it superficially, puts these immigrants in a rather distinct position from others. Particularly, at least in the case of Chicago, because there is nothing predetermined about working with samba. On the contrary, it is a choice based on the observation of the existence of a narrative about Brazil and a market for samba.

Miscegenation, racial democracy, fun, sensuality, 'samba in the blood' are ideas and characteristics that need to be constantly reaffirmed. In this repetitive process, cultural workers transform themselves not only into heralds or representatives of existing samba and Brazil narratives but also into producers and consumers, similar to Carmen Miranda and others that came before and after her. In fulfilling the expectations created by the stereotype, they strive to invent the mythical Brazil and Brazilians that fits the existing fantasy and the imagination of those who are occasional or regular customers. In the struggle to maintain a place for samba in Chicago's culture market, they establish and deepen relationships with individuals of other social and ethnic groups who become their customers and, through these encounters and the expression of differences and expectations, they create what Bhabha (2007: 2) calls innovative sites of collaboration (and contestation). In other words, the immigrants who live from cultural exploitation not only need to 
transform themselves or transform the commodity that they 'sell' but to produce metamorphoses in the milieu where they integrate - above all when it is impossible to survive exclusively from the demand created by their own social and ethnic group.

This article demonstrates, through an ethnographic study of Chicago Samba, a Brazilian musical ensemble, that samba and the Brazilians who reconstruct it, circulate within Chicago repeating old narratives tangled in new webs of meanings, paradoxically creating new spaces of sociability and cooperation between normally separate and distant social groups. They build 'corners of the world' that temporarily break down borders of all types. In the effort to give life to the narratives that open the market to their products, they recreate them and, in the process, create dialogues and sociabilities that subvert them: kinds of niches of resistance to the dominant narratives regarding their own and their host culture. Even though the entry and departure from these niches signal temporary abandonment as well as return to the dominant codes, these encounters, no matter how brief, leave in those who venture into them vestiges of and desires for metamorphosis.

\section{Chicago Samba: how it all began}

The story of samba in Chicago began in the last years of the 1980s when Moacyr Marchini and Claudio Peppe got together to create the Chicago Samba School. Until then, Made in Brazil was the only Brazilian group playing this music in the city. ${ }^{3}$ Moacyr says that Made in Brazil was a wonderful group that drew him many times to the Bulls Jazz Club. He would pay a six-dollar cover charge, drink a beer and although charmed by the music of the group, he couldn't help but regret the non-existence of “a more Brazilian musical beat, something stronger, with which the Brazilian immigrants here would identify because, although what they played was very pretty, it was jazz, Brazilian jazz."

3 Made in Brazil was the name given to the Breno Sauer Quartet since 1979, when he started to play more consistently in the Bulls Jazz Club. Founded and directed by Breno Sauer, who immigrated to Chicago in 1973, the group again changed its name and became Som Brazil in the early 1980s. Apart from its founder and Neusa Sauer, his wife, many Brazilian musicians and non-Brazilians went through the group. The group was also responsible for the immigration of many Brazilian musicians tothe city between 1975 and 1995 
When Moacyr explains that Made in Brazil's music did not satisfy the cultural hunger of Brazilian immigrants in Chicago, he doesn't mean, unlike José Ramos Tinhorão, to question its value or Brazilianness (Perrone 1986). Like Nara Leão (Castro 2000:268), he probably wants to insist that the Brazilian audience for bossa nova is quite restricted and that the "pure samba" is the "true tradition" of Brazilian people. Nara, however, not only recognized the limited scope of bossa nova but claimed - in capital letters - that it was a boring style which did not excite her at all.

Many Brazilians and non-Brazilians who move in and around Chicago samba agree with Nara. Fernanda, 32 years old, born in northwest Paraná and a singer with the forró band, Terra Brasil, does not hide her boredom and even discomfort when Americans immediately connect Brazilian music and bossa nova. She confides that she does not like the style at all and even though she has given it a try, she can't sing it because, she says, "it is a music with no life and it doesn't have the emotions and ups and downs of the sertanejo."' "It's not suitable for dancing", she adds, comparing bossa nova with samba and forró.

Who really insists on the need for a connection between music and dance is Evaldo Jr., 36, born in Manaus in the Amazon, guitar player and vocalist for Chicago Samba: "to me, music has to do with dance! I know that there is an instrumental part to it, and people want to show their talent and so forth, I myself respect that but, for me, the most important is to make everyone dance!"

It was probably in that sense that Moacyr affirmed that the Brazilian music available in Chicago until then was not sufficiently Brazilian. He was speaking for himself, in the sense of his own preferences, but they also reflected the preference and taste that had become popular in Brazil since the 1930s. During this period, the radio stations with the biggest audiences, Mayrink da Veiga and Nacional, promoted samba so insistently that, in 1937, folklorist Luís da Câmara Cascudo confided that these radio stations diffused only "samba and samba and samba and samba," completely eclipsing other genres (Cabral 1990:133).

Despite local protests, such as Cascudo's, samba quickly became

4 Currently the most popular music style in Brazil, "Sertanejo" or "Música Sertaneja" had its origins in the countryside of Brazil in the 1920 (www.en.wikipedia.org/wiki/M\%C3\%BAsica_sertaneja). 
synonymous with Brazil with the help of radio and government promotion. Born out of the encounter and collaboration between classes and races (Vianna 1995), the samba that becomes synonymous with Brazil is then interpreted and proclaimed by leftist political groups and by the City of Rio de Janeiro as a genre whose purest and most authentic expression is found in the slums and is revealed in the annual carnival parades (Sandroni 2001). Thus essentialized, samba begins to express itself in the acrobatics of the mulatto with a cavaquinho and a tambourine, and in the Baiana dance that, in the words of Geraldo Pereira's song "shakes, shakes, tying knots in the hips, leaving the youth with their mouths watering."

Samba, the musical genre, and samba, the dance, become inextricably linked. Thus, if Brazil is samba and samba is dance, consequently Brazil is also dance and, according to that belief, Brazilians prefer the musical genres that lead to dance, but not necessarily to samba. When Evaldo Jr. says that "all music must lead to dance" it is not to samba that he is referring, but to reggae and rock and roll, genres that led him to play music. He is one of many who have discovered Brazilian music, particularly samba, in the United States: "For me, American music was better than Brazilian, but by playing with Chicago Samba I've realized that Brazilian music is much richer..."

Thus, if Brazilians identify with samba when they encounter it away from Brazil, it is not because it was their preferred musical style, but because it is a central element of the dominant narrative about Brazil to which anyone can easily resort in their condition of immigrants away from home and in need of identity support to compensate for the symbolic and emotional losses of immigration. It is to that extent, and as a result of the need for compensation, that samba turns into "something stronger with which Brazilians can identify," says Moacyr when comparing it to the Brazilian jazz played by Made in Brazil.

To the need for compensation must also be added the demands of "a segmented system particularly sensitive to race and ethnicity", as noted by Gustavo Ribeiro (1997) in a study on Brazilians in San Francisco. The pressures to identify with samba must be understood in this context that also includes the demands of contemporary cultural processes. Yet, despite these pressures, Brazilian immigrants who work with samba know full well that Brazilians appreciate many other dances. But, as they move away from the Brazil of their experiences and immerse themselves more deeply in the 
demands of the market for exotic cultural goods, they almost come to forget that not all Brazilians like samba.

Samba is so much lauded as a component of Brazilian nationality that Brazilian immigrants often forget that this exaggeration is more a part of a narrative, and how elements are arranged in it, than part of their own experience. Although aware that not everyone likes Brazilian samba, Moacyr has had a hard time dealing with its rejection by certain groups, individuals or environments. For this reason, he often felt something between disappointment and surprise when witnessing that the samba, which so readily moves Brazilians, bores Americans, Mexicans and other groups not familiar with it.

\section{Reencountering Brazil through a Cuban immigrant}

While boring some, samba fortunately attracts others because it was through a Cuban immigrant that Moacyr got involved with samba in Chicago. Married to a Brazilian-American whom he had met in São Paulo, where he lived, Moacyr came to America in January 1985 when he was 26 years old. He found a Chicago completely hidden in snow. Tan and excited when he arrived, little by little he found that the energy that he had brought from Brazil was fading. His English was horrible and this prevented him from seeking employment in the field in which he was educated, advertising. The not-so-obvious differences between him and his wife when they lived in Brazil were becoming more visible and unbearable every day. They lived in Cicero, a mixed area bordering both black and white areas. He explains that there was a permanent tension and he heard of cases of black families who bought a house in the area and the next day found their garage fire-bombed or car windows broken by neighbors. However his wife seemed to ignore the segregation, which was hurting him so deeply, and that too was one of their many areas of contention.

In his first year in Chicago, Moacyr studied drawing, English and even cooking! He worked in a restaurant, cooking and washing dishes and eventually learned that there were many more opportunities for survival than only those afforded by his profession in Brazil. By caring for his daughter, working in the restaurant and taking classes, he endured his first Chicago winter.

In the summer of 1985, Moacyr met Dom Heriberto Dominguez for the first time at a game of the Flyers Soccer Club. Heriberto was there, with 
several percussion instruments, playing samba..$^{5}$ Moacyr approached him and offered to play. Enchanted with Moacyr's performance, Heriberto invited him to be part of the group. Weeks later the group performed at the Navy Pier. Moacyr remembers that the music played was not such a big deal, but the carnival costumes that the girls wore were beautiful and his participation in the show was the greatest pleasure he had since setting foot in Chicago. At that time, with his attention divided between the girls dancing and his memories of his first Chicago winter, it occurred to him that working with samba might be an alternative among others presented.

But it was not until a year later - already divorced - that he met Claudio Peppe, who became his partner in the creation of the Chicago Samba School. Although mainly employed in construction, Cláudio was already part of the Brazilian music scene in the city and occasionally played for Made in Brazil. At the meeting, in the house of fellow Brazilians, Moacyr and Claudio found that, besides sharing an interest in samba in Chicago, their families lived in the same neighborhood in São Paulo and that Moacyr used to frequent Camisa Verde e Branco, the samba school owned by Cláudio's family.

At the beginning, the group was composed of Moacyr and Claudio; Jairo Escudero, a Brazilian who worked with translation; Rick Ricardo, a Panamanian; Gerardo Galhardo, a Mexican who worked with Claudio in construction; and Carlos Melendez, a Costa-Rican. They rehearsed for six months, twice a week, roughly five hours each time. This dynamic facilitated the development of support and solidarity among them.

So many miles away from its origin, samba seemed to arouse in Chicago the same wish it did in Brazil: that of bringing together people from all walks of life, who would not otherwise meet, with music, dance and joy. Moacyr remembers that the shows and rehearsals were always a party: "Gerardo, the guy who played the rattlexxx, was totally nuts! The Panamanian, who played the agogo, used to destroy one agogo per night! I don't even know how to describe it! The group had a very good energy. We didn't know where so much enthusiasm came from! “

5 The Flyers Soccer Club was founded by a group of Brazilians in the 197os. See http://encyclopedia. chicagohistory.org/pages/1542.html 


\section{Towards professionalization}

Cláudio had to return to Brazil and, soon after, Gerardo, the Mexican, rented a place for the group in the Flat Iron Building, Wicker Park, an old Polish neighborhood which, after World War II, was settled by Puerto Ricans. At first they paid rent of 50 dollars a month. At the time, during the last months of 1988, Wicker Park had not yet gone through the gentrification that has since transformed it into a trendy neighborhood with strong artistic and multicultural appeal.

Now composed of twenty or so members, the Chicago Samba School met weekly for samba jams and some Brazilian women always showed up to dance and enjoy themselves. It was almost a samba school in the Brazilian sense! And this was exactly Moacyr's idea: to realize the project of founding a samba school in Chicago in partnership with Claudio. Not everyone who played really knew what they were doing, but the group rehearsed every week. The word spread and every week more Brazilians joined the party.

Soon the school was invited to play on Thursday nights at the Hot House, a club specializing in World Music. From the start, Brazilian night was always packed. Approximately five hundred people filled the place and danced all night. Brazilians, Americans and Hispanics gathered, and the weekly meeting was full of energy and emotion. According to Moacyr "it was something new and very forceful, something coming from the roots, the heart, you know? It was a very beautiful thing!"

People from the neighborhood and others who usually hung around, all knew about the weekly "party" and many would join. The Chicago Samba School played until the club shut its doors at half past two in the morning but nobody would leave because they wanted the group to keep playing. So, the musicians would move to the sidewalk while they played. In a few minutes the street was theirs: upset motorists and residents would call the police and, once in a while, someone would end up in jail.

\section{From Chicago Samba School to Chicago Samba}

After his second marriage, Moacyr moved to St. Louis and the administration of the Chicago Samba School was left to his partner Steve Carow who initiated a complete restructuring of the group to give preference to professional musicians. During this period of selection, Moacyr met 
Luciano Antonio, a Brazilian guitarist and student of classical music at the University of Missouri, Kansas City. Moacyr invited him to play in the group. Gradually, Moacyr and Steve replaced amateur musicians with professionals and the group increasingly moved away from its previous format as a sort of ongoing, informal jam session where everyone comes and goes. They took the helm of a regular band, in which the relationship between components was more professional and working conditions more clearly established from the beginning.

At this time, the group moved to the Mad Bar. As before at the Hot House, the group received a fixed fee regardless of the take at the door. It began receiving $\$ 800$, which eventually reached $\$ 1,200$. Luciano says that Thursday nights were crowded. However, after a few years, the clientele began to drop and the bar owner cancelled the contract. It was then that the group moved to The Note (all these clubs and bars were located a few hundred meters from each other). At the Note, the band needed to grow musically because payment now depended on good performance, professionalism. They worked hard, introducing new songs and arrangements. Moacyr and Steve hired new musicians, mainly those who played American jazz, and removed the word "school" from the band name: they became just Chicago Samba. During the first months, the group received no payment since it was still trying to recoup the lost clientele.

Observation of the various stages Chicago Samba has gone through over the past fifteen years makes it possible to identify many factors that explain its ups and downs. When it was the only band playing samba and popular Brazilian rhythms, some fans would get tired of always seeing the same people playing and dancing and would try other alternatives among the thousands that nightlife in Chicago offers. In addition, there is now less room for big bands, and other Brazilian bands are performing different days of the week and in more accessible places. Chicago Samba's next move from The Note to the Hot House responded to these two facts: the emergence of Bossa Três, composed of members from Chicago Samba itself, and the new location of the Hot House on Balbo Street in the West Loop, one block from the Hilton, on Michigan Ave.

With the change, Chicago Samba began to reach a wider though more unpredictable audience, no longer just the Brazilians and their friends or the people of Wicker Park attracted by the liveliness of the presentations at 
Mad Bar or The Note. In addition to club members, the Hot House sent its monthly schedule to a list of fifteen thousand people and advertised in several newspapers.

I, for instance, became aware of the program through a Cuban neighbor. Knowing of my research with Brazilian artists, he told me about Brazilian night at Hot House. Although a club member, he explained that he had never gone to see Chicago Samba because his own "community" was very rich culturally and offered many events, leaving no room for approaching “other communities." He suggested that Hot House's promotion of an "international" image was not so convincing because the shows were mostly supported by ethnic communities. This was confirmed at least in the case of Chicago Samba. The move from Wicker Park to downtown was not particularly profitable because it did not facilitate participation by Brazilians, because most Brazilians lived closer to Wicker Parker and the new location was more expensive.

\section{Chicago Samba: other metamorphoses}

It was during the Mad Bar season that Shirley Vieira discovered Chicago Samba. She was taken by her brother who was visiting the city and persuaded her to go see a Brazilian band that played in Wicker Park. Married to a white American and living for almost ten years in Mount Prospect, she had become accustomed to her comfortable and quiet suburban life. Until then, Chicago seemed far, not even a desirable place to visit except during the Christmas season to see the lights and decorations. Happy to encounter a bit of Brazil in Chicago Samba, she began to dance. But she felt weird dancing samba. Although born in Rio, she had never really liked samba, always preferring rock and roll, and forró and frevo when visiting her relatives in the Brazilian northeast. For some strange reason at the Mad Bar, samba was making her heart beat faster and feel more Brazilian. Dancing just for the pleasure that this encounter with Brazil was giving her, she felt quite surprised when the wife of one of the band members approached her. Praising her performance, the woman made the following invitation:

- Don't you want to do a show with us?

— Me? Naked? No! And not in a bikini either!!

But the woman explained that it was a carnival show, with costumes. 
Shirley accepted the invitation and got $\$ 150$ to dance for less than two hours. These private gigs were sporadic, but Chicago Samba played weekly. Shirley offered to dance and soon became one of the band's attractions. However, by the time she became completely involved with this job, a period that coincided with the end of her marriage, the band fired her on the grounds that dance was attracting more attention than the music itself and this was not the purpose of the band.

When Shirley left the band, she realized, as did Moacyr some years earlier, that working with samba offered much more than just \$75 per hour every now and then. The work with samba allowed her to get close in different ways to Americans and immigrants alike, whether or not Brazilians. Through working with samba, she became a sort of Brazilian ambassador. Nevertheless, she never felt that she was representing an underdeveloped Brazil, plagued by crime and misery from which many people fled, and from which she herself also often hid. The country she rediscovered through samba seemed to redeem her from all the misery of the other one, offering instead gifts and possibilities, joy, exuberance, beauty and new job opportunities. From then on she specialized in the production of shows for events and private parties.

The seed she had planted in the hearts of the Chicago Samba patrons germinated so much that when Edilson Lima went to see the group's weekly performance at The Note in early 2001, Moacyr immediately invited him to give samba lessons during intermissions. Edilson's history with samba in Chicago, like Shirley's, also began by chance, but unlike hers, his relationship with dance and musicals was not casual. He had worked on several TV shows in São Paulo, where he lived, and also did shows in night clubs and proms. He had been in the city for only a few months when other Brazilians with whom he studied at Truman College took him to see Chicago Samba at The Note.

Desperately missing Brazil and a bit frustrated with his immigrant life, which had led him to gain more than ten pounds, Edilson surrendered to dance as a ritual of purification. Enchanted and intrigued by his style and energy, several people congratulated him on his performance and asked if he was Brazilian. He did not think twice about giving lessons when he received Moacyr's invitation. He began by teaching on the dance floor, but everything changed when he had the idea of bringing apprentice dancers to the stage: from a simple samba instructor he quickly became a showman. He also noted 
that everyone liked to participate and a little participation was very important to many. But he did not simply want people to feel important, wanted, and so forth; above all, he wanted them to approach Brazilian culture playfully and with humor. He explains: "it is very difficult for someone who has never danced samba to dance it well at first. The tendency in these cases is that they feel shy. So, it helps when you have someone to help break down barriers by saying silly things and guiding the steps: put the hand on the head, shake, and go down there ...”

\section{Chicago Samba: the Hot House show}

Although created by two Brazilians starved for the company of their countrymen, the professionalization of Chicago Samba imposed the challenge of dealing with a diverse audience. Luciano explains that the main characteristic of its audience is a love for dancing. In this sense, those who go to hear the band are more interested in moving their body than simply listening to Brazilian music. On my first visit to the Hot House, I found the space enormous for the four or five dozen people who were there. It was nearly midnight when I arrived accompanied by Ana Rita, a friend, and Al, the chef of the restaurant where she worked as a waitress. I found the place beautiful and pleasant but, in spite of the small audience, I was unable to concentrate on details because we arrived during Edilson's show, which was so exuberant that it prevented me from paying attention to anything else. Edilson was wearing white trousers and shoes and a light transparent tunic, also white, embroidered with blue sequins. With a strong voice, he talked, danced, laughed and joked incessantly with the audience. He ordered people to shake, let go, surrender to the adventure of experiencing the body with the ease of "Brazilians".

Despite his perfect English, there is no hint in his speech of an interest in assimilation. Aware that his function is to sell a cultural commodity, he does so by following the rules of an economy which, as explained by Bourdieu (2006: 19), "can function only through a constant and collective repression of the economic interest." Thus, Edilson wants to achieve far more than just attracting public to his show. Instead, he wants to draw people into a deeper and more permanent encounter with Brazilian culture. He does not want the adventure to begin and end there; he wants to engage people enough to bring 
them many times to the Hot House, perhaps, also to Edilson's private classes and, who knows, even to Brazil? However, in order to achieve his purpose, he has to add to the merchandise, "samba" or "Brazilian Dance," an illusion that one is before something truly extraordinary, which transcends the moment, turning it into an encounter, a passion, even a conversion.

Edilson's show both attracted and repelled me; it made me feel uncomfortable and diminished. I found his representation of "Brazilian culture" too stereotyped. He presented himself as the embodiment of the stereotype, a figure belonging more to the realm of postcards than to reality. ${ }^{6}$ Besides the basic steps of samba, he also taught the movements of other dances, particularly axé. Unlike me, everyone seemed to be having a great time with his enthusiasm, games and cultural excess.

My discomfort reminded me of the reaction of those involved in the old controversy between the historian Pedro Calmon and the novelist José Lins do Rego regarding the image of Brazil projected by Carmen Miranda in the United States. In an article published in the newspaper A Noite, in June 1939, Calmon opened the discussion by arguing that the sudden success of Carmen Miranda on Broadway was bad because it could create the impression that Brazilian music was reduced to just samba and this was a false and dangerous generalization. Lins do Rego responded that samba was an essential part of the national soul (McCann 2004: 63-65). I have always seen Lins do Rego's reaction as populist and excessively patriotic, but quite understandable at a time when, against the current of European colonialism, Brazil was trying to forge an image of itself from elements that had previously been criticized and denigrated, principally its racial mixture. From this perspective, samba, a symbol of mestizaje, had to be defended at all costs, and valued as symbol of a nation that was finally accepting what it really was.

There, in the Hot House, almost seventy years after the famous controversy, I was affected by it. There were, however, some differences between the feelings that mobilized Calmon and Lins do Rego and mine. One is that at the time when Calmon complained about the limitation of Carmen Miranda's representation of the nation, Brazilian music was unknown. Since then,

\footnotetext{
6 I am here following Bhabha (1994:95) for whom the stereotype "must always be in excess of what can be empirically proved or logically construed" and Ramos-Zayas (2008:272), who defines cultural excess "as the representational and ideological strategies through which certain bodies are viewed as overflowing with meaning and never naturalized."
} 
bossa nova had bloomed. I not only knew that Brazil no longer presented itself internationally only through samba, but was in Chicago to study the diffusion of bossa nova. But even so, I found the performance excessive. It was certainly fun, lively and engaging, but excessive. I crossed my fingers that no non-Brazilians would approach me looking for the fulfillment of Edilson's promises, who vaunted his spectacle as a glimpse of Brazil: "come with us to an incredible journey to Brazil ... and shake your booty baby!!!!!!!!!!!!!!!”

Indeed, Al, our non-Brazilian guest, did not accept that I was not as lively as Edilson. Despite the bossa nova and other existing representations of Brazil in the U.S. market, he demanded that I live up to that specific fantasy: bodily ease expressed in rhythmic leg and hip movements crowned with a broad smile. Although half drunk and stumbling, he clumsily answered Edilson's call and surrendered to the joy of samba. Unsatisfied that I was not dancing samba with him and others, he shouted, "what kind of Brazilian are you?"

There was, in his question, no real desire to deepen his knowledge about my particular Brazilianness, but rather a sense of disapproval. I was frustrating his expectations about the fantasy to which he wanted to surrender that night and it bothered him. Even the Brazilians who frequented the place had difficulty understanding a Brazilian who did not samba. I began to realize that, by being the only native who distrusted the sorcerer's magic, I was hindering not only Edilson, but all the others who were charmed by him.

I mistrusted the magic because, like Calmon and Lins do Rego, I was still interpreting those images of Brazil as positive or negative. After I frequented Chicago Samba shows more assiduously and came closer to musicians, dancers and other patrons, I shifted my attention from critical evaluation of images and stereotypes to observation of the encounters and relationships that were made possible through them. Thus, instead of only seeing dominant strategies of exoticism and bemeaning of the other, I began to understand these stereotypes as mediators between different cultures. From then on, I entered the game and began to enjoy its excesses like everyone else.

In addition to the fantasies to which he gave life that night, Edilson indirectly apologized to the public for such a small audience by mentioning the prior week's show which, according to him, had been full of tourists from all over, particularly from European countries. He mentioned French, Italians and Russians and how they had fallen in love with Brazilian night in Chicago. 
He also announced a competition for king and queen of samba on January 6 , 2007 that would reward the winner with free entry to all Chicago Samba gigs.

On January 6, 2007, I arrived at the club minutes before the music started. Luciano had let me know that the first part of the show would be calmer: bossa nova and choro. Nicole Tader gave me a ride and introduced me to several people sitting at a table to the right side of the stage. Among them was Marlin Exton who some hours later would be elected King of Samba 2007. I got so involved with the conversation that I did not notice that the section devoted to bossa nova and choro had come and gone. I returned to watching what was happening on stage when Edilson announced the opening of the contest. That night, only those who had classified on the two previous Thursdays competed. His friendliness and enthusiasm in the few minutes of our conversation made me carefully watch Marlin's performance. He competed with another black man who was about two decades younger. As Edilson's student, Marlin did not follow the tradition of Brazilian male samba dancers with steps focused on heels. Mixing traditional masculine and feminine steps and not sparing grace and enthusiasm, Marlin Exton won and was crowned King of Samba 2007.

\section{Samba Junkies}

Marlin and Vanyette, his wife, call themselves samba junkies. Every Thursday night they go to the Hot House. They regularly arrive before the music begins and only leave at the end. For Marlin, the encounter with Chicago Samba is the beginning of fulfilling a dream nurtured for decades: to know the world envisioned in the film Black Orpheus.

Marlin was born in 1962 in Harvey, Illinois, a south Chicago suburb. Until now, most of the city's population is African-American, 79.57 percent, according to the 2000 census. Son of a gospel singer, he grew up in a musical environment and also played piano. He saw the movie Black Orpheus in 1974, when he was only 12 years, and fell in love with the country where different people came together and danced happily. He watched the movie with his mother, who loved to dance and was also attracted by the rhythm and steps of samba.

After the movie, he wondered: is there really a place like this, where black people can be so happy? And he dreamed of knowing that land seemingly so 
distant and unreal. Black Orpheus became one of his favorite movies. In adolescence and adulthood, whenever he thought of the film, he also thought of how nice it would be to meet someone from Brazil so that he could distinguish reality from fiction. He loved the way people danced in the film, their joy, and the air of happiness. He also loved the rhythm, but he did not even know the music was called samba. The fantasies inspired by the movie became even stronger and more intangible because, he recalls, despite the consequences of the civil rights struggle, there was still a lot of racial conflict during the 197os and 1980s. Racism was still very prominent. Blacks and whites did not venture beyond the borders of their territories. Black Orpheus charmed him because it brought a glimpse of a distant paradise where people of color danced and smiled happily.

He waited three decades until that afternoon in which he was face to face with the culture that inhabited his dreams for so long. He saw an advertisement for a presentation of Gingarte Capoeira at Governors State University where he worked as a janitor. Delighted with the spectacle, he approached the capoeira instructor, Marisa Cordeiro, to find out about capoeira classes and at that time he met Maristela Zell, a professor at the university where he works who was responsible for contracting the show. The two women proved friendly and receptive, as he expected, which encouraged him to maintain his desire to get closer to Brazilians. He quickly found a place on his calendar to attend Brazilian events with Vanyette.

Only a few weeks later, at the celebration of Brazilian Day (September 7, 2006), the couple first heard Chicago Samba play, in the Logan Square auditorium, along with other Brazilian music groups. They watched the Chicago Samba show including Edilson Lima's performance. That night, watching samba dancers in their carnival costumes, Marlin felt transported to the Rio carnival and this initial contact with samba increased his confidence to get closer to Brazil.

His first visit to the Hot House, soon afterwards, only deepened the feeling he had of familiarity and comfort on that remote day when he saw Black Orpheus. He was delighted with the opportunity to learn to dance samba with a teacher as passionate and full of energy as Edilson. It was the beginning of a devotion that lasts until today. Among Brazilians, he has always felt comfortable because, he says, he was never judged by his color. He adds: 
We love to go see Chicago Samba play. They make us feel comfortable. They make us feel as if we're actually part of what they are doing... They're very appreciative of people who come to see them, and we like that because we've seen musicians who completely ignore the people who come to see them... They make you feel like, thank you for coming to see us... we'll play as hard as we can for you... They make you come back... Everybody we've met who goes to the Hot House, we love! We've made so many friends! All nationalities... Whites, Indians, Russians, Italians, Argentinians... I know that music creates many bridges between people, but it's mostly Brazilian music that makes me want to dance and smile. With Chicago Samba, we hug people because it's a good energy going on... We're totally addicted to it!

While Marlin has still not realized his dream of "moving to Brazil before his death," he is content with getting a taste of Brazil through the fragments presented by Chicago Samba, probably the only place where he can really live the Brazil of his fantasies: "When we're out there, dancing, everybody dances with us and it makes me dream that I'm in Brazil... and one of the guys of the Chicago Samba said that he loves the way I dance because it reminds him of home, and I feel so proud, so honored, so well accepted, and all I want is to have fun! “

Since his only contact with Brazilians is with those linked to the production of Brazilian culture, Marlin assumes all Brazilians have the same qualities. For instance, he is enchanted by the idea that "Brazilians" are attached to traditions, love samba and its composers and that everyone sings old carnival songs with passion and nostalgia. He is also quite impressed by what he has learned about racial mixture in Brazil and how samba came from that mixture, that communion. As a musician, he loves Brazilian rhythms because he feels that they come straight from the soul, such is the power with which they reach his ears. But what particularly impresses him, and he considers quite tricky, is the fact that Brazilian music does not always reveal the feelings carried by the lyrics: "It's tricky because they play a song that sounds cheerful and happy, but when you understand the lyrics, you think, hey, it's sad! Meu sapato já furou [My shoe got a hole], for example, is very sad but it sounds happy!"

In the U.S., he explains, when the music sounds sad so do the lyrics. Thus, if it is a happy song, it sounds that way from the first note, which is completely different from what he observed in Brazilian music. He 
remembers that when he knew nothing about the meaning of the lyrics, he thought that Brazilians only sang about joy and happiness. Puzzled, he asks: why is samba like that?

He concludes that samba simply expresses who Brazilians are and what Brazil is like. He admires what he sees as Brazilians enjoying life, how though busy they make time for a coffee, a beer, or a conversation. He also learned that he can rely on the word of the Brazilians who work with samba: he can count on them whereas he cannot always count on Americans. He proudly says that he is now an American-Brazilian. He feels very well treated by Brazilians and he loves it: "I was crazy about jazz and now my life is just samba and forró!

Moacyr and Luciano explained that there are several others like Marlin who "catch the fever" and religiously go to watch Chicago Samba every Thursday. Some go for three, six months and others who go for two years without missing a single Thursday! During more than a decade of Chicago Samba, Luciano says that he has seen "many clusters of fanatics ... If I think of a certain time at Mad Bar, I still remember the faces that came nonstop for a while and then disappeared, left.”

Steve Fisher, also born in 1968, in the affluent suburb of Western Springs, is another of those who became addicted to the samba played in the city. A professor at Northwestern University, he used to go to bed regularly at 10:30 pm. Thus, he thought himself totally nuts when he began to leave home for a program that started at $11 \mathrm{pm}$ !

It all began in the summer of 2000 when some of his friends who were traveling to Brazil invited him to see Chico Cesar at the Old Town School of Folk Music. Until then he did not even know where Brazil was. He found the show entertaining, but he did not give it more thought until the Northwestern International Center for Comparative Studies promoted Brazil Week. There he met Moacyr, who invited him to attend a percussion workshop he was teaching. Steve persuaded a friend to accompany him: "let's go, let's do something different, "cultural"!" There, in the workshop, they took the instruments without really knowing what to do with them and got into the middle of the cacophony. Steve found it all very noisy, but held steady. Moacyr invited him to show up at The Note, where he was playing on Thursday starting at 11pm. Steve could not believe that he was leaving home at 10:15 pm to pick up his friend and arrive at 10:40 pm at The Note! During the first time watching Chicago Samba, he paid particular attention to Edilson's performance, which he found even 
much funnier and more engaging than Chico Cesar's. What he experienced was quite extraordinary for him, a white man born and raised in the suburbs, having tons of fun with Chicago Samba and Edilson Lima!

The following week, he enrolled in Edilson's samba class at Latin Street Dancing. He and another man were the only men in the midst of many women! Among them, he even met mothers and daughters learning together. After the first three classes he realized he needed to practice the steps he learned in the only possible place: The Note with Chicago Samba. Not even the cold of winter discouraged him from leaving Evanston where he lived to drive to Wicker Park where samba made everything warm and cozy. He used to stay in the back of the room, practicing what he had learned in his samba classes: one, two, one, and two. Then one day his only male classmate, also non-Brazilian, told him: "Look, if you really want to dance like a Brazilian, you have to pretend you're a woman and roll! Don't worry about moving your butt!" While not questioning the advice and having only Edilson and the usual image of the colonized as effeminate ${ }^{7}$ as references, Steve says it took him three to four months to feel comfortable enough to accept the suggestion to release his hips and roll. He finally let his prejudice go and, following his classmate's advice, he realized that it was something quite liberating and fun. He amused himself unaware that his extravagant performance was also the reason for the entertainment of those who knew that Brazilian males do not need to roll when dancing samba.

Like Marlin and Vanyette, Steve learned that Brazilians enjoy life more than Americans, "they often have to wake up early, but they still go out dancing, they think it is worth enjoying life to the fullest.” By being a bit closer to Brazilians, Steve has overcome the common prejudice among his friends, which equates sexiness to pornography: "My friends who think like me and go see Chicago Samba and people dancing samba only see the sexual and pornographic side of it." Yet, he recognizes that Brazilians cannot kid themselves because there is indeed much sex involved in Brazilian dance. He insists that this is an essential component of the culture, especially the way sexuality is expressed in dance. Despite acknowledging these characteristics, he emphasizes his experience of the dance as a space for encounters and amusement

7 Memmi (1991), Fanon (1963; 1967), and Sinha (1995) have discussed the feminization of colonized men in the depictions of colonizing powers. 
more than anything else. Thus, what most attracts him to Chicago Samba is the energy that surrounds it. Moreover, he thinks bossa nova is boring and hated the time when he visited Rio de Janeiro and his friends did not take him to the samba schools in the slums with the excuse that it was dangerous. They only took him to bars that played bossa nova.

Steve was one of the fanatics who would listen to Chicago Samba every week at The Note. He explains why: "I do not need company to go to Chicago Samba, I go alone! What is good about Chicago Samba is just that: you can show up there, alone, and it's okay. We all know each other and everyone is friendly and receptive! The group is almost always the same!" According to what he observed at The Note, half of the audience - which he estimated at about one hundred and one hundred and fifty people - was made up of Americans and the other half was Hispanic and Brazilian. He says that it was like a family, and that he made friends of different ethnicities and walks of life. He no longer goes as assiduously as he did at first, but he still thinks that it "is an excellent gathering place and everybody has fun!"

Unlike Marlin, Vanyette and Steve, who became involved with Brazilian culture in Chicago, Nilda Soto encountered Brazil as a tourist in Rio de Janeiro in the summer of 2002. Born in Puerto Rico in 1966, Nilda moved to Chicago in 1974, when she was 8 years old. The daughter of a university professor and a high school history teacher, she has a bachelor's degree in business and nursing and a master's degree in education. She was making vacation travel plans when a Mexican colleague, who had just returned from Brazil, told her wonderful things about the beaches, people, and carnival. Taking advantage of the promotions right after the Sept. 11 crisis, she got tickets and hotel rooms at unbelievably cheap prices!

She was so delighted with the trip that when she returned to Chicago she wanted to meet and know everything about Brazil. She bought all kinds of CDs and started going to events related to Brazil. During a Chicago Samba performance at The Note, she met Pompeu, a Brazilian, fell in love and soon got married.

She explains that Brazil charmed both her and her sister, who traveled with her, because they had the privilege of meeting a native, introduced by a Mexican friend. Besides showing them a less well-known Rio de Janeiro, he introduced them to a philosophy of life that led them to inquire deeply into their own: 
This tour guy was so wonderful that he even got us to meet his family! And got us to participate in carnival, and I loved it! I loved everything: the people are always happy! I feel like it doesn't matter how bad things are, life is still good. That's what I saw... I don't see it here... Here people always complain about everything: oh my god, I have to do this and that. But in Brazil people were always nice, happy, smiling... I have never met anybody who has gone to Brazil and not loved it... Like, my sister was attacked in Brazil, at knife point on the beach... and even with that experience I still love Brazil... What I have to say is that of all the places that I've traveled, Brazil is the one that I love most. First, it was Spain, later it was Greece, but now it's totally Brazil! I never had any intention of going there, because, you know, it was South America. It wasn't on my list...

As well as Marlin, Vanyette, Steve and Nilda there are many other nonBrazilians involved with samba in Chicago. Marcos Oliveira ${ }^{8}$ and Luciano Antonio, for example, married Mexican-Americans who used to attend Chicago Samba shows. The success of and the need for Edilson Lima's samba lessons at the group's show also indicate a regular non-Brazilian clientele. However, Shirley Vieira and Paulinho Garcia ${ }^{9}$ insist that Chicago Samba's public has always been composed mainly of Brazilians and, in the final analysis; it is this ethnic audience that supports it. Shirley explained that, after changing the weekly show from The Note to the Hot House, the crisis faced by Chicago Samba was a direct consequence of the absence of Brazilians, accustomed to the proximity and the cost of The Note. For his part, Paulinho believes that, unlike the bossa nova crowd, Chicago Samba patrons

are young people who have just come from Brazil and still live the fantasy of jumping up and down... There are not many Americans, or other non-Brazilians, and those who go are brought by Brazilians themselves. I mean, the audience for samba here is not really American ... I think that if it weren't for the Brazilian patrons, Chicago Samba would not survive because Americans

8 Marcos Oliveira was born in Rio de Janeiro in 1963. He has been Chicago Samba's percussionist since 1994, when he arrived in Chicago. As a teenager, he took part in the samba circles that formed spontaneously in his neighborhood, but had never played professionally. When he migrated to Chicago, he had already got his degree in Accounting from the Junior Morales College and in Brazil worked as a tax consultant.

9 Paulinho Garcia, 62 years old, born in Belo Horizonte, immigrated in 1979 to work in Breno Sauer's Made in Brazil. One of the most well established Brazilian musicians in the city, in 2010 he was chosen by the Chicago Tribune as the Chicagoan of the Year in Jazz. 
don't go... Americans like beautiful and sophisticated carnival costumes. They go to these carnivals in grand style to see a fantasy of Brazil that we recompose. This audience will not go to the Hot House, sit down and see people jumping up and down and a band playing loud. But it attracts some Americans desirous of experiencing a Brazilian carnival and satisfied with what Chicago Samba offers...

The statements of Marlin, Steve and Nilda, however, testify to the presence at Chicago Samba shows of many Americans with a desire to approach or remain near Brazilian culture. Brought by their Brazilian friends or boyfriends, or like Steve, simply risking new "ethnicities" in a city full of such nightly offers, the fact is that Chicago Samba attracts more than just Brazilians. In the several Thursdays I went to see the group, I also found black, white and Hispanic Americans besides the Brazilians.

It is possible that some patrons that I counted as Whites, Blacks or Latinos, were also Brazilians since, as Marcos Oliveira noted, it is not always possible to identify Brazilians by physical appearance. He taught me the final proof of identity: you learn who is a Brazilian by their reaction to certain songs: according to this thesis all Brazilians become happy when they hear Gonzaguinha's O que é, o que é.

The Chicago Samba Brazilian public is believed to range from the Brazilian Consul all the way to Brazilian maids, and include students at local universities. In general, they have in common the fact of being single or, when married, have adult children. Among the non-Brazilians, the majority are students or young professionals who are attracted by the idea of Brazil through friends. Many have visited or lived in Brazil, and others have dated or wanted to woo Brazilians. Some are divorced; many are single, and there are also some rare couples. Besides these general characteristics, many also take samba lessons with Edilson Lima, Dill Costa, or Rachel Montiel. Despite differences of nationality, gender, marital status and specific motivations for acquainting themselves with "Brazilian Night" or a samba band in Chicago, there are also common reasons for the "fever" or "fanaticism.".

The testimonies of Marlin, Steve and Nilda suggest that those who regularly attend Chicago Samba gigs do so because they think it is an enjoyable and comfortable experience. Marcos Oliveira agrees: "we have always had the desire to make the visitors feel like they are at home. And when we become more intimate, we play, bullshit, and we all feel at ease ... We are musicians, 
but they see that we are people just like them..." He adds:

I think Americans prefer to go to Chicago Samba than to other Latin dances because in Chicago there is less cultural pressure regarding samba. If you go to a salsa club and dance awkwardly, you're more likely to be reprimanded by other dancers or the audience than if you're in the Hot House ... We always leave people at ease, I tell them: "we do not know if you can dance or not, we want you to come and put what you're feeling out ... the way you think it should be done. If this is the right way to dance, it doesn't matter, after all, I myself do not know how to dance! So when someone comes saying she cannot dance, I say, who cares?”

Depending on the level of "cultural pressure," it may be that the privilege of dancing samba clumsily is not extended to cities like Framingham (MA), Newark (NJ) or Pompano Beach (FL), where there are large concentrations of Brazilians. As a consequence of this freedom, the gatherings around Chicago Samba, as described by Marcos Oliveira, are more like a therapy than one more test in a life already full of them. Luciano, for his part, insists on the specificity of Chicago Samba shows:

Chicago Samba brings all sorts of people together. It's like the United Nations. I think it's the energy, the joy of the music, the sensuality. Men, for instance, no matter where they come from, Indians, White Americans, Mediterraneans or Latinos, they all feel fascinated by the sensuality of the dance. Samba is a bit tricky and paradoxical: the percussion is heavy, but the samba dancer is light and almost floats on the floor...

Whether attracted by the magic, strangeness, or wildness contained in the narratives of samba and Brazil, or simply by the aesthetics and sensuality of the dance, many continue attending classes, concerts and other events sponsored by the group. This has nothing to do with abstract powers of seduction, but with the feeling of welcome that they find in the "communities" formed around these cultural productions. Thus, the commonality among those "addicted" to samba is the need to establish links, relationships, and to feel their differences acknowledged. Not by chance, they are also immigrants to Chicago even when American. Or else they are individuals like Marlin and Steve who, because of some sense of exclusion, or need and desire for adventure, feel encouraged to distance themselves from their own social groups to open up new worlds. 


\section{Far from ethnic comfort: the private parties}

However, Chicago Samba does not experience only good energy. Several musicians have referred to the frustrations encountered at private parties as one of the biggest challenges to the diffusion of Brazilian music in the region. Some communities are more close-minded than others according to Marcos who offers the example of the Mexican and Puerto-Rican communities: ${ }^{10}$

It is very difficult to get into a community such as the Mexican, which has a culture like "here is water, there is wine", completely different from ours! They are traditionalists, nationalists! For them, they are in first, second, third and fourth place and there is no space for anyone else. We had experiences where in the same night, we played with salsa or Mexican bands and we clearly heard them say: how much longer will these guys play? Several times we played and they remained still, bored, but as soon as we'd finish our show, a Mexican band would start playing and everybody would get up and start dancing ... That would give us such a feeling of failure!

The apparent rejection Chicago Samba has experienced and will probably continue to experience is not restricted to a particular culture, but it is, above all, a common reaction to a first contact with otherness. Or it may simply be a preference for one musical genre over another, as Becker (2008) explains in his study of jazz in Chicago. In regards to samba, however, the difference is that, besides the cleavages of class, generation, region and others that are at the basis of musical preferences, there is also the question of dealing with the Other, whether immigrant, colonized, underdeveloped, or primitive. Moacyr notes that people pay attention to the music, applaud, but are not involved, or at least not involved to the point of getting up and dancing. But, he argues, "this happens with any group, not only with us ... But we, because of our culture, want to get people involved." Indeed, several group members, who refer to the indifference or rejection of "Americans", "Mexicans" or "Puerto Ricans" to Brazilian music, reveal their disappointment at not being able to involve these groups right away with the music.

10 Marcos's proximity to the Mexican world, because he is married to a Mexican-American, should be enough to avoid such generalizations. I have no doubt that he is aware of the variety of possibilities existing under broad categories such as "Mexican community" or "Puerto Rican community." Here he probably referred to very specific segments of these communities, but I did not question his propositions about it and he proceeded without making the appropriate relativization. 
Nevertheless, as noted by Moacyr, any unfamiliar song or cultural symbol may be rejected. In relation to Chicago Samba, Moacyr has learned that, in general, Americans like "plumes and sequins, which are one of our brands, like our carnivals and our good energy." But, he adds, "there is a big distance between enjoying a carnival parade and getting involved with Brazilian culture! Getting involved has to do with how open people are to new things, or how tired they are of all that exists here and want to be part of something else. “

Appreciation for aspects of Brazilian culture, nostalgia of those who have lived in Brazil, or even the fantasy of recreating carnival in the United States are some of the reasons Chicago Samba is hired for private parties. Moacyr recalls the story of a couple that met at one of their gigs, began dating and later hired Chicago Samba for their wedding party. When the band arrived at the party they noticed that there were only white Americans there who had nothing to do with Brazil. They asked themselves: what to do now? Thus, the band played Beatles and other rock and roll as well as samba and bossa nova and everyone liked it.

Like Sergio Buarque de Holanda (2002), Moacyr insists that flexibility is not only a characteristic of the band, but also of Brazilian culture. He says that everything they produce is very adaptable and there is always room for more mixes, "fusions." He states that "the authentic" is not something rigid, and he adds: "if we had to think of authenticity there would be no bossa nova..." On the other hand, he recognizes that the band cannot escape its roots because what it sells is above all a cultural product. Their shows always offer a little of everything: choro, bossa nova, samba so that "people always know something."

An enthusiastic reaction to Chicago Samba, however, only happens when there is a sufficient number of Brazilians or Brasilophiles, according to Luciano:

Even when Chicago Samba gives the same show it presents at the Hot House to a private party, the show just does not come off because people do not understand and folks do not feel the music. Sometimes we feel somewhat restricted, trying to force people to dance, trying to make the party happen the way we have in mind and plan, but people do not understand what is going on and prefer to stay seated, as if waiting for what will happen next. (...) But when there is 
a sufficient number of Brazilians whom the music touches, it brings out that emotional thing of missing Brazil, of feeling at home and speaking Portuguese. (...) So, when there are enough Brazilians the atmosphere contaminates everyone around, whether Indian, Hispanic or French. (...) So, that's how it is: we start to play a set of dance music and when Brazilians are around, they immediately begin to dance and whoever's around begins to imitate, and there you go: a dance party all night long!

\section{By way of conclusion}

The material analyzed in this paper shows Chicago Samba to be a kind of "corner of the world" where Brazilians and non-Brazilians get together mediated by samba. Life-stories of Moacyr Marchini, Luciano Antonio, Shirley Vieira, Marcos Oliveira, Edilson Lima, Fernanda and Evaldo Jr. reveal that their engagement with samba, even when casual, is a choice based on an observation of the advantages of this specific labor market in comparison with the general market for immigrant labor. These advantages are not all necessarily economic. As Shirley suggested (p. 9-10), there is also the symbolic capital offered by few professions open to them. The artist or cultural worker is never just cheap immigrant labor; above all, $s /$ he is a representative of the culture whose goods s/he negotiates. As such, instead of becoming nobodies which is the usual fate of immigrants, those working with cultural goods have a value recognized by their countrymen and also by natives and other ethnic groups in the host country.

Brazilian immigrants who engage professionally with samba in the United States do not always do so because they had a special relationship with it before they came. Instead, many of them, like Moacyr, Marcos, Shirley and Fernanda, had no working relationship at all with music or dance but took advantage of invitations to enter that world. When they did, they never wanted to leave because they were rewarded in many ways. Luciano Antônio, for instance, reflects with irony and humor about his career: "life is funny, I came to Kansas City to study classical guitar and ended up playing pagode in Chicago!" Although already involved with music, Evaldo Jr. had no particular interest in samba. Before his casual meeting with Luciano in a Chicago bar, Evaldo Jr. played in rock and roll and reggae bands. Fernanda never thought of singing professionally. They all got involved with samba after immigrating 
and after verifying that such involvement could turn into a more valued form of integration.

Obviously, without an already existing narrative about Brazil, there would not have been this job market or the possibility of this kind of integration. Thus the stereotypes that compose the narrative are the architects of the desires and fantasies that drive people to constructing the "corner of the world," inhabited by Chicago Samba. In this corner, individuals, lulled by samba and the fantasies it raises, get together with others belonging to ethnic and social groups that otherwise do not usually meet.

Because it is an ethnic product in a city with a small Brazilian population, samba requires a special kind of initiation that goes beyond simply mastering the dance technique: it requires living and dreaming a mythical Brazil along with others. Even though manufactured to sell samba, the ambience ends up welcoming everyone, including Brazilian immigrants. Samba in Chicago is not only a mirror that reflects remote and intimate desires but is also proof that paradise exists not just south of the equator but there in a kind of cultural free zone constructed by Chicago Samba's weekly presentations.

Far from the city's (and Brazil's) hegemonic social relations, Chicago Samba becomes a kind of safe haven where those who venture there create an opportunity to see themselves and others through different lenses. Mediated by the appeal to hybridity and miscegenation contained in samba, Brazilians and non-Brazilians rediscover themselves as well as Brazil, Latin America, the United States, and the geopolitics of Chicago. They also discover the flexibility and limits of all kinds of stereotypes. Marlin, for instance, found that the distant Brazil of Black Orpheus was within his reach right there in Chicago, only a few dozen miles from home. It was there too that Nilda discovered that Brazil is also just around the corner; the encounter completely changed her life and led her to reconstruct Latino identity in Chicago. Steve also challenged the limits of a suburban white American and realized, through dancing samba, that Brazilians enjoyed life more than he did. Bridging miles of social distance, the 'Consul' and 'maid' smile at each other complicit in the narrative. Chicago Samba reinvents Brazil, geopolitics and the samba itself, and creates the conditions for an effective cultural hybridity "that entertains difference without an assumed or imposed hierarchy" (Bhabha 2007:5). Thus it challenges simplistic explanations that involve classic polarities, which though helpful for understanding the divisions and conflicts between 
individuals, "do not include the existence of affection between people, participation in altruistic activities, where the hegemonic and the subaltern are mutually interdependent" (Canclini 1998: 347).

\section{REFERENCES}

BESERRA, Bernadete. 2003. Brazilian Immigrants in the United States:

Cultural Imperialism and Social Class. New York: LFB Scholarly Publishing.

BESERRA, Bernadete. 2007. "Sob a sombra de Carmen Miranda e do carnaval: brasileiras em Los Angeles." Cadernos Pagu 28(1):313-344.

BECKER, Howard. 2008. Outsiders - Estudos de Sociologia do Desvio. São Paulo: Zahar, 2008.

BHABHA, Homi. 1994. The Location of Culture. London and New York : Routledge.

BOURDieU, Pierre. 2006. A Produção da Crença - Contribuição para uma economia dos bens simbólicos. Porto Alegre: Editora Zouk.

BUARQUE DE HOLANDA, S. 2002. Raízes do Brasil. 26a Ed. São Paulo: Companhia das Letras. CABRAL, Sérgio. 1990. No tempo de Almirante: Uma história do radio e da MPB. Rio de Janeiro: Livraria Francisco Alves.

CANCLINI, Néstor G. 1998. Culturas Hibridas. São Paulo: EDUSP.

CASTRO, R. 200o. Bossa Nova: The Story of the Brazilian Music that Seduced the World. Chicago: Chicago Review Press.

DAVIS, Darien. 2008. "Before we Called this Place Home: Precursors of the Brazilian Community in the United States". In Clemence Jouet-Pastre and Leticia Braga (org.), Becoming Brazuca: Brazilian Immigration in the United States. Cambridge: Harvard University Press. pp. 26-55.

FANON, Franz. 1963. The Wretched of the Earth. New York: Grove Press.

FANON, Franz. 1967. Black Skin White Masks. New York: Grove Press.

MACHADO, Igor J. R. 2004. Estado-nação, identidade-para-o-mercado e representações de nação. Revista de Antropologia 47 (1): 207-233.

MCCANN, Bryan. 2004. Hello, hello Brazil : Popular Music in the Making of Modern Brazil. Durham e London: Duke University Press.

MEMMI, Albert. 1991. The Colonizer and the Colonized. Boston: Beacon Press. PERRONE, Charles. 1986. Bossa Nova at Home and Abroad. Paper presented 
at the V International Congress of Latin American Studies Association.

Boston. (See www.bossanova.mus.br/artigos/)

RAMOS-ZAYAS, Ana Y. 2008. "Between 'Cultural Excess 'and Racial

'Invisibility': Brazilians and the Commercialization of Culture in Newark".

In Clemence Jouet-Pastré and Letícia Braga (Ed) Becoming Brazuca:

Brazilian Immigration to the United States. Cambridge: DRCLAS/Harvard

University. pp.271-286.

RIBEIRO, Gustavo. 1997. "Street Samba: Carnaval and Transnational Identities in San Francisco". A paper presented at BRASA IV Congress, Washington, DC, November.

SANDRONI, Carlos. 2001. Feitiço Decente : Transformação do Samba no Rio de Janeiro (1917-1933). Rio de Janeiro: Jorge Zahar.

SAYAD, Abdelmalek. 1998. A Imigração ou os Paradoxos da Alteridade. São Paulo: Edusp.

SINHA, Mrinalini. 1995. Colonial Masculinity: The 'Manly Englishman' and the Effeminate Bengali' in the Late Nineteenth Century. Manchester and New York: Manchester University Press.

VIANNA, Hermano. 1999. Samba : Popular Music and National Identity in Brazil. Chapel Hill and London: The University of North Carolina Press.

\section{About the author}

Bernadete Beserra, PhD Anthropology, University of California, Riverside Professora associada do Departamento de Fundamentos da Educação da Universidade Federal do Ceará.

\section{Address}

Rua Joãozito Arruda n. 2160

60824-075 - Fortaleza - Ce

Telefones: 8532752002 e 8587339090

Email: bernadetebeserra@yahoo.com.br 